\title{
Retraction Note: Effects of uric acid on endothelial dysfunction in early chronic kidney disease and its mechanisms
}

Yu Wang and Xiaorong Bao*

\section{Retraction}

The Publisher and Editor regretfully retract this article [1] because the peer-review process was inappropriately influenced and compromised. As a result, the scientific integrity of the article cannot be guaranteed. A systematic and detailed investigation suggests that a third party was involved in supplying fabricated details of potential peer reviewers for a large number of manuscripts submitted to different journals. In accordance with recommendations from COPE we have retracted all affected published articles, including this one. It was not possible to determine beyond doubt that the authors of this particular article were aware of any third party attempts to manipulate peer review of their manuscript.

Received: 26 January 2015 Accepted: 4 March 2015

Published online: 31 March 2015

\section{Reference}

1. Wang Y, Bao X. Effects of uric acid on endothelial dysfunction in early chronic kidney disease and its mechanisms. Eur J Med Res. 2013;18:26.

* Correspondence: jinshankidney_js@126.com

Department of Nephrology, Jinshan Hospital affiliated to Fudan University, No.1508 Longhang Road, Jinshan District, Shanghai 201508, China

\section{Submit your next manuscript to BioMed Central and take full advantage of:}

- Convenient online submission

- Thorough peer review

- No space constraints or color figure charges

- Immediate publication on acceptance

- Inclusion in PubMed, CAS, Scopus and Google Scholar

- Research which is freely available for redistribution

Submit your manuscript at www.biomedcentral.com/submit

() Biomed Central 